\title{
Use of Internet and Electronic Games by Adolescents at High Social Risk
}

\author{
Maria Paula Magalhães Tavares de Oliveira ${ }^{\mathbf{1}}$ \\ Sociedade Brasileira de Psicologia Analítica, São Paulo, SP, Brazil \\ Projeto Quixote, São Paulo, SP, Brazil \\ Leticia Antunes Dias Cintra \\ Graziela Bedoian \\ Rosimeire do Nascimento \\ Rodrigo Rodrigues Ferré \\ Projeto Quixote, Universidade Federal de São Paulo, São Paulo, SP, Brazil \\ Maria Teresa Araújo Silva \\ Departamento de Psicologia Experimental do Instituto de Psicologia da Universidade \\ de São Paulo, São Paulo, SP, Brazil
}

\begin{abstract}
Handling digital tools can be an important means of social inclusion. The aim of this study was to investigate Internet use and electronic gaming in 60 teenagers at high social risk, participants in Projeto Quixote. We sought to characterize type of activity, frequency, duration, company, location, and purpose of Internet use and electronic gaming, as well difficulties managing the web. Most of the interviewed teenagers were enrolled in school, and used Internet and electronic games to interact with friends and family, especially for communication and entertainment. The adolescents reported that they learned to use these devices by themselves and that they knew the risks associated with these practices. However, the results show that they had exposed themselves to several risks. Gender differences were observed. The urge of empowering parents and educators to develop skills to promote social inclusion is discussed, as well as the importance of monitoring use, in order to prevent inappropriate or excessive use.
\end{abstract}

Keywords: Adolescents, internet, electronic games, social vulnerability, risk.

\section{Uso de Internet e de Jogos Eletrônicos entre Adolescentes em Situação de Vulnerabilidade Social}

\section{Resumo}

O domínio de ferramentas digitais pode ser importante via de inclusão social. O presente estudo visou investigar o uso que 60 adolescentes em situação de vulnerabilidade social, participantes das atividades do Projeto Quixote, fazem da internet e de jogos eletrônicos. Procurou-se caracterizar tipo de atividade, frequência, duração, companhia, local, finalidade do uso de internet e de jogos eletrônicos, incluindo dificuldades encontradas no manejo da rede. A maioria dos adolescentes entrevistados está na escola, usa internet e jogos eletrônicos, interagindo com amigos e familiares, principalmente para comunicação

Mailing address: Rua da Consolação 3741, conj. 21, São Paulo, SP, Brazil 01416-001. Fone: (fax) 011 30635280. E-mail: mpm_fto@uol.com.br

Nota de agradecimento: Gostaríamos de gradecer a colaboração de Vinicius Magnum pelo auxilio na aplicação de questionários e digitação de dados. 
e entretenimento. Os participantes relataram que aprenderam a usar sozinhos e que sabem de riscos associados a essas práticas. Entretanto, os resultados mostram que eles se expõem a condutas de risco. Diferenças de gênero foram observadas. Discute-se a necessidade de capacitar pais e educadores para estimular uso que desenvolva competências visando inclusão social assim como a importância de acompanhar o uso para prevenir prática inadequada ou excessiva.

Palavras-chave: Adolescente, internet, jogos eletrônicos, vulnerabilidade social, risco.

\section{El Uso de Internet y Electrónicos Juegos por los Adolescentes en Alto Riesgo Social}

\section{Resumen}

Manejo de herramientas digitales puede ser importante medio de inclusión social. El objetivo de este estudio fue investigar el uso de Internet y de los juegos electrónicos por 60 adolescentes en alto riesgo social, participantes en las actividades llevadas a cabo por el Projeto Quixote. Hemos tratado de caracterizar el tipo de actividad, la frecuencia, la duración, la compañía, la ubicación y la finalidad del uso de internet y juegos electrónicos, así como las dificultades encontradas en la gestión de la web. La mayoría de los adolescentes entrevistados estaban matriculados en la escuela, utilizan internet y juegos electrónicos para interactuar con amigos y familiares, sobre todo para la comunicación y el entretenimiento. Los adolescentes informaron que aprendieron a utilizar estos dispositivos por sí mismos y que conocían los riesgos asociados con estas prácticas. Sin embargo, los resultados muestran que se habían expuesto a diversos riesgos. Diferencias de género fueran observadas. Se discute la importancia de empoderar a los padres y educadores a desarrollar habilidades orientadas a la inclusión social así como de hacer el seguimiento del uso para prevenir la práctica inadecuada o excesiva.

Palabras clave: Adolescentes, internet, juegos electrónicos, vulnerabilidad social, riesgo.

Technology has become part of our daily life and is beneficial in several areas. The Internet facilitates communication and interaction in ways that was previously impossible. It is popular with people of all ages, especially children and adolescents. Electronic games and video games are a main entertainment attraction for this population. The digital world offers new forms of creativity, learning, entrepreneurship, and innovation; to make use of these opportunities, however, certain abilities are required (Palfrey \& Gasser, 2011). Access to technology is insufficient; digital alphabetization is necessary. In socially vulnerable populations, the Internet can facilitate social, educational, and professional inclusion. However, it is unclear to what extent such populations have access to the Internet and to opportunities to learn how to use these resources. There are few studies in such populations in Brazil. The expression "social vulner- ability" refers to the population of high social risk situations in communities characterized by minimal education, drug abuse, delinquency, violence, and lack of access to culture and quality health care (Bedoian \& Madalena, 2008).

A survey to investigate the nature and consequences of the risks associated with online exposure of children and adolescents in Brazil, ICT Kids Online Brazil, was conducted in 2013 and employed the same methodology used in the European version, EU Kids Online (Barbosa, 2014). In European countries, inequalities have been observed related to Internet use and the opportunities it offers, as consequences of socioeconomic differences (Ponte, 2014; Ponte \& Simões, 2013), leading to differences in digital skill and safety (Livingstone, 2014). In the Brazilian edition of the survey conducted in 2012, it was revealed that children and adolescents from disadvantaged social classes start to use the In- 
ternet later in life than do those from higher social classes, and know more about it than do their parents (Guzzi, 2014).

In Brazil, Internet access is expanding. This has been accompanied by greater availability of technological resources, such as computers, tablets, and mobile phones. Instituto Brasileiro de Geografia e Estatistica data (IBGE, 2012) revealed that, in 2012 , there was a $6.8 \%$ increase in Internet from the previous year (5.3 million new Internet users within one year), and a gradual increase in web access has been verified in recent years. Among the age groups analyzed, the range of 15 to 17 years used the Internet the most (76.7\%). Recently, Queiroz (2015) classified the country as digitally mature: since $63 \%$ of its 84 million Internet users report engaging in at least eleven different online activities. However, the study revealed a disparity between social networking activities, engaged in most, and online courses, seeking employment, or personal purchases, engaged in least.

Previous research conducted with university students in São Paulo revealed that the percentage of students who go online daily is higher than those who watch television daily, and that a significant number of students play video games with high frequency. Further studies on excessive video gaming in student populations are required (Suzuki, Matias, Silva, \& Oliveira, 2009).

Internet activities may fascinate children and adolescents, and excessive use or misuse of the web may cause many problems (Abreu, Karan, \& Spritzer, 2008, Hautefeuille \& Vélea, 2010; Young \& Abreu, 2011). Excessive exposure and exposure to inappropriate content for age, maintaining virtual instead of face-to-face relationships, spending excessive time online at the expense of other activities, forms of violence, such as bullying and sexual harassment are examples of problems associated with inappropriate Internet use (Abreu, Eisenstein, \& Estefenon, 2013; Young \& Abreu, 2011). Electronic games can facilitate development of many skills, such as quick thinking, decision-making, and coordination. However, excessive playing may have adverse consequences, such as abandonment of other activities, including study, sports, and social or family interaction. Furthermore, both inappropriate and excessive Internet use and video gaming have health consequences, such as postural injuries, lack of exercise, and sleep deprivation. These behaviors may also become addictive (Abreu et al., 2008; Young \& Abreu, 2001), as included in sector III of the DSM V (American Psychiatry Association [APA], 2013).

Knowing how teenagers use the Internet and electronic games is important to encourage use which contributes to their development. In addition, early detection of abuse or misuse allows preventive interventions. Considering these aspects, the present study aimed to investigate Internet use and electronic gaming in socially vulnerable adolescents, participants in Projeto Quixote. Projeto Quixote is a nonprofit Organization of Civil Society of Public Interest (OSCIP), which, since 1996, has acted with the mission of transforming the story of children, youth, and families at high social risk situations, through integrated clinical attendance, educational, and social actions; and of generating and disseminating knowledge. Linked to the Universidade Federal de São Paulo (UNIFESP), Projeto Quixote invests in art, education, and healthcare as strategies to bond with these young people (Bedoian \& Lescher, 2007). From its inception until the end of 2015 , the Projeto Quixote assisted more than 11,000 children and adolescents from poor communities in which dysfunctional families, alcohol abuse, drugs and violence are part of everyday life. The project has headquarters in Vila Mariana and units of assistance in the city center, Praça da República and Luz area, in addition to maintaining a work with educators that address adolescents roaming the city streets.

Projeto Quixote operates in two areas, Education and Research and Attendance. The area of Education and Research seeks to study the practice to produce knowledge to support public policies aimed at children, youth, and families at high social risk. Through courses, supervision, and consultation with technical and social educators from all over Brazil, Projeto Quixote 
facilitates exchanges and sharing of experiences. This research is an activity of this sector aimed at collecting information on the behavior of adolescents in relation to the Internet and video games, to support educational practice. In the $A t$ tendance area, affective bounds are built through ludic strategies, which enable spontaneous demands, attended to by a multidisciplinary team. Several programs belong to the Attendance area, such as the Pedagogic, Clinical, Education to work, Family Attention, Street Approach and Urban Refugees (Bedoian, 2014; Bedoian \& Fender, 2010; Bedoian \& Madalena, 2008).

Among children and adolescents who sought care at the headquarters of the Projeto Quixote in Vila Mariana in 2012, the year that the present data were collected, the majority was referred by institutions and about a third had already made use of drugs in their lifetime. A fifth was serving or had already served some socio-educational measures (warning, community service, reparation, assisted liberty, or semi-liberty). Although the majority are students, $38 \%$ had spent time on the street and $13 \%$ reported performing some activity to earn money. The perception of the Quixote Project educators is that the number of teens with mobile phones has been increasing over the years and that they use these mainly to send messages and listen to loud music. As for the Internet, these educators have the impression that it is mainly used for communication via social networks, for listening to music and sharing photos. They note that adolescents are fond of video games, but cannot evaluate how much, where, and with whom they play. Among those attending the workshops of Education for Work, it was observed that few have e-mail, an issue discussed in order to illustrate to participants the importance of this resource for professional purposes, such as sending résumés and exchanging messages about job opportunities. Taking into consideration all these issues, this project aimed to characterize the type of activity, frequency, duration, company, location, and purpose of Internet use and electronic gaming, including the difficulties and benefits inherent in Internet use in a sample of teenagers attending activities at Quixote Project headquarters.

\section{Method}

\section{Participants}

Sixty adolescents between 14- and 18-years old, who participated in activities offered by the Attendance area at the headquarters of Projeto Quixote, were interviewed from August and December 2012. Ten teenagers attended Welcome workshops (beginning of Attendance) and all others attended specific workshops, such as graffiti, break, soccer, capoeira, etc.

\section{Instruments}

A questionnaire aiming to investigate how adolescents used the Internet and electronic games was developed by the researchers. The questionnaire contained questions about sociodemographic data, and specific questions about Internet use, electronic games, and other recreational activities. Questions included, for example, from whom Internet use was learnt; location, frequency, duration and purpose of use; and difficulties encountered during use. Questions about video games addressed issues such as with whom participants usually play; location, frequency, and duration of play; and type of games played. Some of the questions were from previous research (Suzuki et al., 2009). In addition, the questionnaire included four open questions: "In your opinion, what are the dangers of the Internet; What you do usually do to protect yourself; What do you like best on the Internet"; and "Is there something you do not like on the Internet?" A pilot questionnaire was administered to ten adolescents who attended activities at Projeto Quixote to check the time required for answering it and the clarity of the questions. Adjustments were made, resulting in the final version.

\section{Procedure}

The questionnaire was administered by trained investigators on the days adolescents attended to their activities in the Projeto Quixote, just before or shortly after the activity. Subjects were asked at random to participate in the study. After a brief explanation of the objectives and 
ethical considerations, they signed the Informed Consent. They were assured that the data would be confidential. Questionnaire completion took on average 20 minutes.

\section{Data Analysis}

Collected data were entered into a database and analyzed using the software program, SPSS. Only the valid answers for each question were included in analysis. Thus, in the manufacture of tables and graphs the percentage was calculated based on the universe of responses for each question, having been discarded blank responses. Chi-square was used to analyze categorical variables, and when $n<5$, Fisher's exact test. The Student $t$ test was used for continuous variables. All tests were two-tailed. For analysis of open questions, similar responses were grouped and keywords identified. These key-words were then tabulated and quantified according to previously used procedures: (a) identification of the central idea of the comment; (b) fragmentation in segments of comments that express more than one idea; (c) registration of the main topic of each segment in a key expression corresponding to the literal transcription of the speech; (d) key expressions were grouped in categories based on their equivalence; (e) classification of the categories (Almeida, Bizeto, \& Silva, 2007). The socioeconomic status was evaluated by the Criterion Brazil, defined by the Brazilian Association of Research Companies (ABEP, 2012).

\section{Results}

The sample consisted in 60 adolescents, 34 males (57\%) and 26 females (43\%), and the average age was 15 years $(S D=1.12$, ranging between 14 and 18). Fifty-three (88\%) adolescents reported being currently studying, the majority attending their final year of elementary school or their first year of high school $(68 \%)$, as shown in Table 1,73.3\% reported living with their parents, $15 \%$ reported living in a shelter, and $12 \%$ answered "another," which mainly meant they lived with their grandparents $(6.7 \%)$ or aunts $(3.4 \%) .10 \%$ of adolescents reported that they had not been home for over six months. When asked about the educational level of their parents, $10 \%$ reported that they were illiterate, $20 \%$ that the household head had eight years of education, $27 \%$ had eleven years of education, and $23 \%$ could not say. The socioeconomic status of the sample was distributed among the classifications $\mathrm{B} 1, \mathrm{~B} 2, \mathrm{C} 1$, and $\mathrm{C} 2$. We also investigated whether these teens had a computer at home; $27.8 \%$ did. Approximately half the sample had mobile phones $(48.9 \%)$. There were no significant differences in any of the sociodemographic variables when compared to gender.

\section{Internet}

Only three participants reported not having used the Internet in the last 12 months. One of them reported that it was because it was expensive and the other reported that it was "because I thought it was not good to use the Internet". When asked about having trouble using the web, the vast majority reported no difficulties (90\%). The problems cited were " $\mathrm{did}$ not know how to write correctly," "difficulty to download and upload", "not knowing how to manage it", "everything is very difficult to get inside my head" and "many things". More than half the respondents said they learned to use the Internet themselves (61\%). There were significant gender differences: more girls than boys learned to use the Internet at school [X2 (1, $N=57)=4,403 ; p=.036$ ], as seen in Figure 1.

Most respondents had email (96.5\%), Facebook (94.7\%), and MSN (86\%); only one girl did not have this app. About half of respondents had Twitter accounts (54.4\%); 19.3\% had a blog.

As seen in Figure 2, online activities, in descending order of prevalence, were social networking (96.5\%), downloading music (91.2\%), studying (86\%), sharing photos or videos $(84.2 \%)$, sending and receiving e-mails (84.2\%), watching movies and series (84.2\%), and seeking information or news $(78.9 \%)$. There were no significant gender differences on these variables. Analyzing the number of different activities performed by the participants, it was observed that $18.8 \%$ performed between one 
Table 1

Socio-Demographic Characteristics of a Sample of Adolescents that Attend Projeto Quixote $(\mathrm{N}=60)$

\begin{tabular}{llll}
\hline & & $N$ & $\%$ \\
\hline \multirow{2}{*}{ Gender } & Men & 34 & 57 \\
& Women & 26 & 43
\end{tabular}

Actual

School

$5^{\text {th }}$ Grade

2

Grade

$6^{\text {th }}$ Grade
$7^{\text {th }}$ Grade
$8^{\text {th }}$ Grade
$9^{\text {th }}$ Grade
$1^{\text {st }}$ High School
$2^{\text {nd }}$ High School
$3^{\text {rd }}$ High School

Housing

Parents

Shelter

Other

$\begin{array}{llrr}\begin{array}{l}\text { Household } \\ \text { Family }\end{array} & \text { Illiterate } & 6 & 10 \\ \text { Education } & \text { 4 Years of Educ. } & 7 & 11,7 \\ & 8 \text { Years of Educ. } & 12 & 20 \\ & \text { High School } & 16 & 26,7 \\ & \text { College/Superior } & 5 & 8,3 \\ & \text { I dont know } & 14 & 23,3 \\ & & & \\ \text { Economic } & \text { A2 } & 1 & 1,7 \\ & & & \\ & \text { B1 } 1 & 7 & 11,7 \\ & \text { B2 } & 12 & 20 \\ & \text { C1 } & 13 & 21,7 \\ & \text { C2 } & 11 & 18,3\end{array}$

and five activities, $61.7 \%$ between five and ten activities, and $18.3 \%$ more than 11 activities. The average was 7.6 (range $0-14, S D=3$ ).

Amount spent on average per week to use the Internet varied greatly. The vast majority spent nothing. The average spent was US\$ 4 (SD $=23.6$, ranging from 0 to US\$ 40) and the median was 0 . No gender differences were observed.

Table 2 displays the answers concerning the frequency, days, average of time, period, and place of Internet use, as well as the practice of electronic gaming. Regarding frequency of use, most adolescents connected the web more than once a week (72\%); approximately half, daily (54\%). Some adolescents use the Internet mainly from Monday to Friday (17\%) and others on weekends (23\%); most use it daily (60\%). The average time online varied widely, as seen in Table 2. It was observed that the boys on average spend more time online than the girls [X2 (2, $N=57)=8.52 ; p=.014]$ :

When asked about the longest time they have been online without interruption, $37 \%$ reported more than ten hours, 10\% reported having been connected for at least 24 hours. Responses varied widely $(M=11,9 \mathrm{~h}, S D=13.7$, range from 2 to 72 hours), with a median of seven hours. Most adolescents usually went online in the afternoon (67\%) and at night (70\%) and $37 \%$ after midnight. No gender differences were observed on this variable. Regarding where they usually connect to the Internet, more than half of teens surveyed reported accessing the network at home (61\%), as shown in Table 2. Analysis of the item "Other" revealed that it corresponds to a relative's home (godmother, grandmother, aunt, 6.8\%); cell phone (2.4\%); computer course (2.4\%); Serviço Social do Comércio - SESC $(2.4 \%)$; mother's work $(1.7 \%)$; or shelter $(1.7 \%)$. It was observed that significantly fewer boys reported using the Internet at Projeto Quixote than did girls [X2 $(1, N=57)=4.311 ; p=.038]$.

More than half the teens had already used the webcam $(58.2 \%)$ and the vast majority of them use the Internet to chat with friends (96.5\%) when in chat rooms, MSN, or on social networks. Half use it to communicate with 


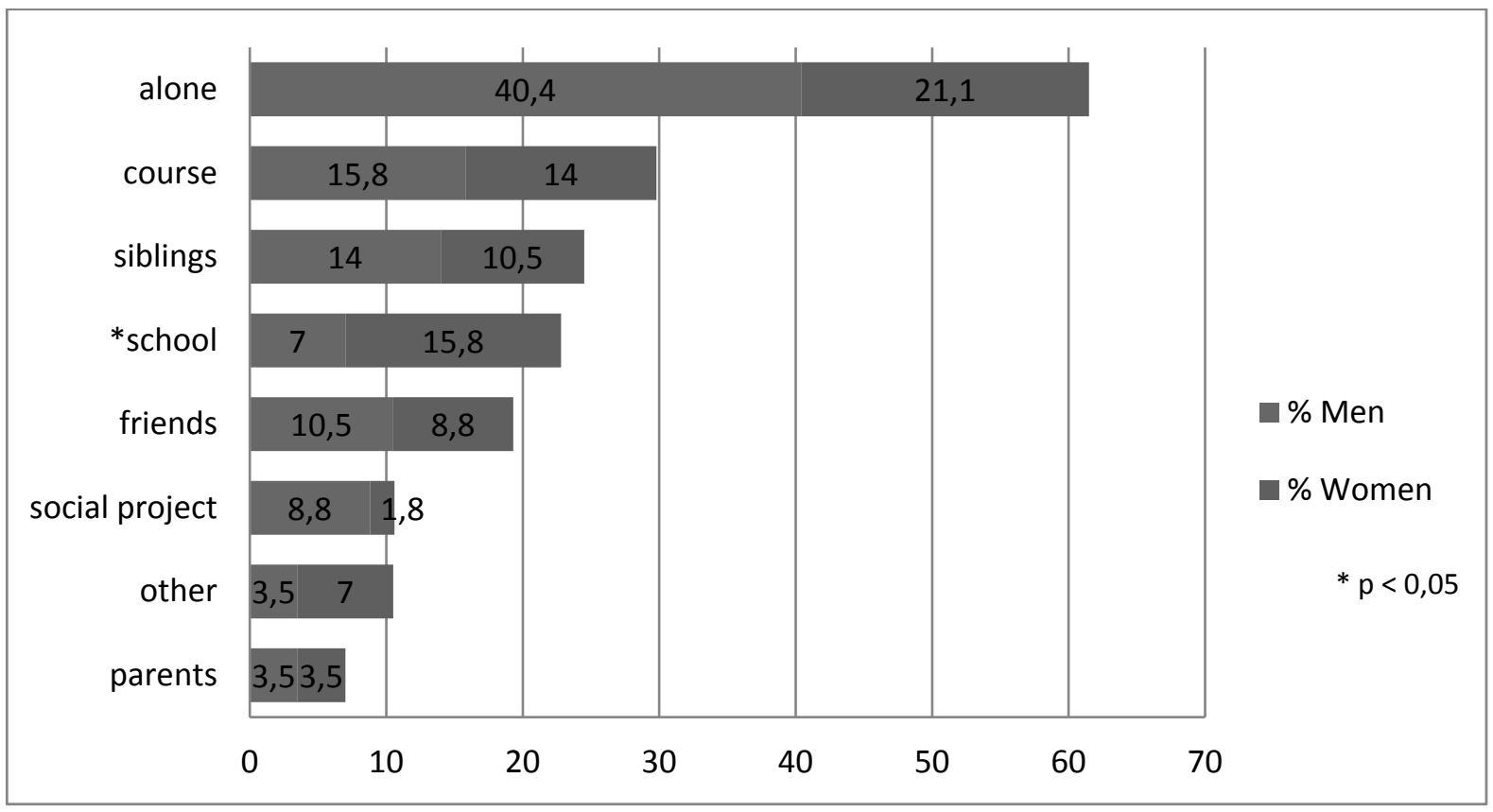

Figure 1. Where or with whom the sample of adolescents that attend Projeto Quixote learnt to use the Internet $(N=57)$.

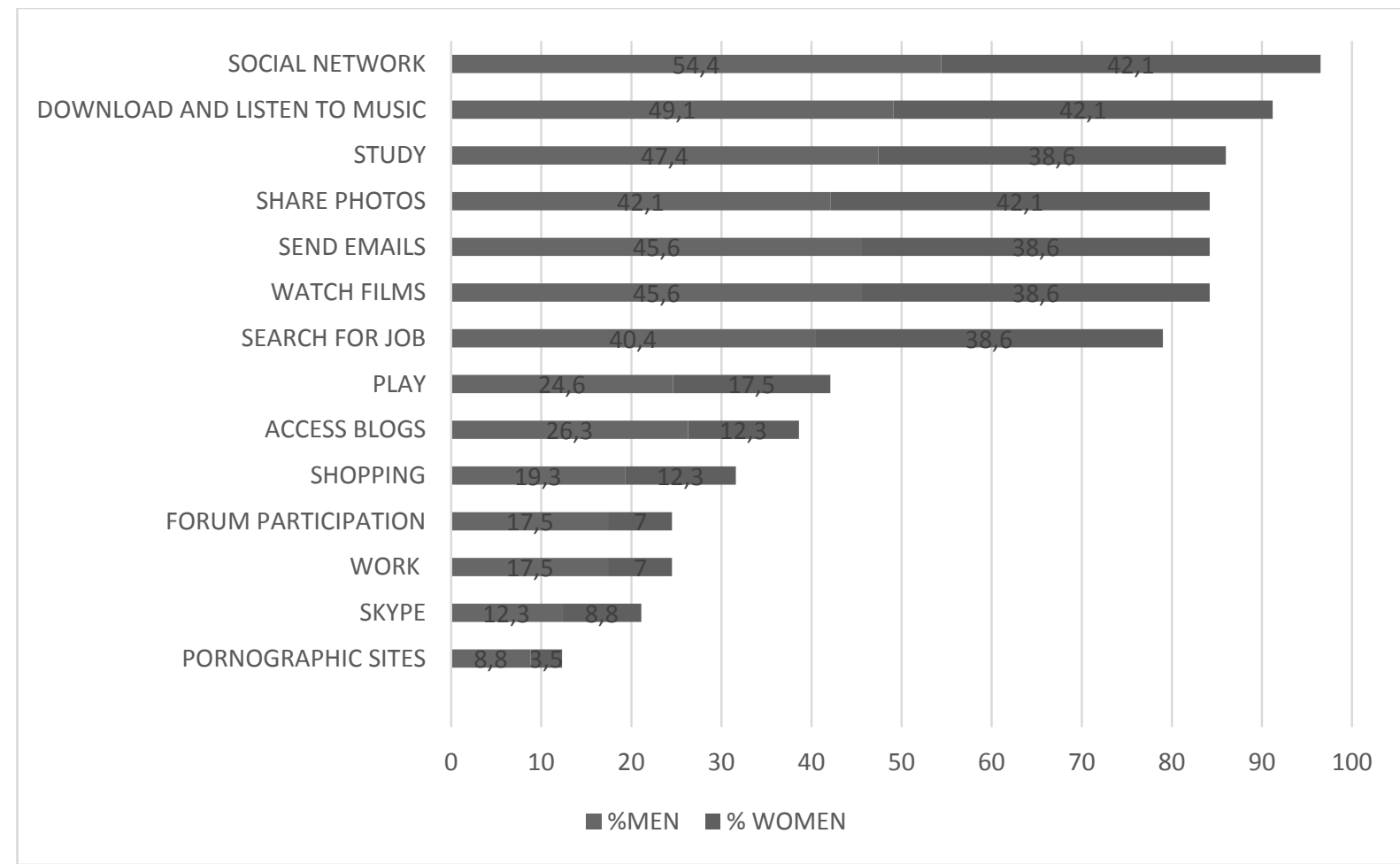

Figure 2. Frequency and percentage of Internet activities in a sample of adolescents that attend Projeto Quixote $(N=57)$.

their families (50.9\%). Approximately a third talk to boyfriend or girlfriend (36.8\%) online; this behavior is most common in girls [X2 $(1$, $N=57)=4,397 ; p=.036]$. Twenty-six percent reported communicating with virtual friends and $8.9 \%$ with a virtual boyfriend or girlfriend. Noteworthy is the fact that $28 \%$ reported talking to strangers. 
Table 2

Frequency, Days, Media of Time, Period and Local that a Sample of Adolescents that Attend Projeto Quixote use the Internet and Electronic Games $(\mathrm{N}=57)$

\begin{tabular}{|c|c|c|c|c|}
\hline & \multicolumn{2}{|c|}{ Internet } & \multicolumn{2}{|c|}{ Eletronic Games } \\
\hline & $N$ & $\%$ & $N$ & $\%$ \\
\hline \multicolumn{5}{|l|}{ Frequency } \\
\hline once per month & 7 & 12,3 & 17 & 29,8 \\
\hline once each 15 days & 4 & 7 & 5 & 8,8 \\
\hline once per week & 5 & 8,8 & 7 & 12,3 \\
\hline more than once per week & 10 & 17,5 & 16 & 28,1 \\
\hline everyday & 31 & 54 & 12 & 21,1 \\
\hline \multicolumn{5}{|l|}{ Days } \\
\hline Monday till Friday & 10 & 17,5 & 14 & 24,6 \\
\hline weekend & 13 & 22,8 & 28 & 49,1 \\
\hline everyday & 34 & 59,6 & 15 & 26,3 \\
\hline \multicolumn{5}{|l|}{ Time Media } \\
\hline less than 1 hour & 3 & 5,3 & 22 & 38,6 \\
\hline from 1 to 2 hours & 16 & 28,1 & 14 & 24,6 \\
\hline from 2 to 3 hours & 12 & 21,1 & 5 & 8,8 \\
\hline from 3 to 4 hours & 7 & 12,3 & 4 & 7 \\
\hline more than 4 hours & 15 & 26,3 & 10 & 17,5 \\
\hline I don’t know & 4 & 7 & 2 & 3,5 \\
\hline \multicolumn{5}{|l|}{ Period } \\
\hline morning & 17 & 29,8 & 15 & 26,3 \\
\hline afternoon & 38 & 66,7 & 33 & 57,9 \\
\hline night & 40 & 70,2 & 31 & 54,4 \\
\hline aftermidnight & 21 & 36,8 & 14 & 24,6 \\
\hline \multicolumn{5}{|l|}{ Local } \\
\hline home & 35 & 61,4 & 40 & 70,2 \\
\hline school & 9 & 15,8 & 6 & 10,5 \\
\hline Quixote & 19 & 33,3 & 5 & 8,8 \\
\hline friends home & 19 & 33,3 & 22 & 38,6 \\
\hline lan house & 16 & 28,1 & 9 & 15,8 \\
\hline telecenter & 9 & 15,8 & 3 & 5,3 \\
\hline others & 11 & 19,3 & 6 & 10,5 \\
\hline
\end{tabular}


In chat rooms, MSN, or on social networks, most adolescents use their real names $(71.4 \%)$, $39.3 \%$ employ nicknames, and $5.4 \%$ create fictitious names. Fourteen percent sometimes pretend to be someone else and 3\% always pretend to be someone else. Inquired about establishing contact with people known on the Internet, $44.6 \%$ reported having virtual friends and $18.2 \%$ a virtual boyfriend or girlfriend. In addition, $37.5 \%$ reported having met and maintained frequent contact as a friend and $5.4 \%$ as a boyfriend or girlfriend; $16.1 \%$ maintained sporadic contact. A significant gender difference was noticed: more boys than girls kept in touch with online friends $[\mathrm{X} 2(1, N=57)=4,978 ; p=0.026]$.

Responses to what they like best on the Internet varied. The possibility of social interaction was cited by $41.3 \%$ (social networks were referred to by $27 \%$ and the ability to talk to people by $14.3 \%$ ), followed by the possibility of keeping up to date $(20.6 \%)$. Half stated there is nothing to displease in the Internet. Others mentioned pornography $(n=5)$, fakes profiles $(n=$ $3)$, advertising $(n=3)$, viruses $(n=3)$, games $(n$ $=2)$, nosy or curious people $(n=2)$, slow Internet $(n=2)$, and spam $(n=2)$.

Concerning what the teenagers find dangerous in using the Internet and what they do to protect themselves, the most frequently mentioned hazards were talking to strangers $(25.6 \%)$, pedophilia $(25.6 \%)$, and viruses (12\%). Harassment and abuse $(n=5)$, hackers $(n=5)$, kidnapping ( $n$ $=4)$, adult sites $(n=3)$, fake profiles $(n=3)$, shopping $(n=3)$, pornography $(n=2)$, and bullying $(n=1)$ were also mentioned. The most frequent response to protective measures taken were " $d o$ not talk to strangers" (37.5\%), "use anti-virus" (18\%), and "avoid sites considered dangerous" $(13.9 \%)$, as well as "not giving personal data" $(n=6)$, "do nothing" $(n=6)$, "not meeting unknown people" $(n=4)$, "going off the Internet" $(n=3)$, "being careful with who to talk" $(n=2)$, and " $n o t$ entering into chats" $(n=1)$.

A third of respondents disconnect from the Internet when interrupted by someone (33.3\%). Twenty-six point three percent reported having had problems related to the web. Different kinds of difficulties were mentioned, arguments ( $n$
$=4)$ and viruses $(n=3)$ most frequently. The vast majority of respondents believe the Internet can be addictive $(94.7 \%)$, and $33.3 \%$ reported having a friend who had suffered bullying via the Internet. Twelve point three percent reported having suffered bullying themselves and $15.8 \%$ admitted having bullied others over the Internet. Gender differences were not observed in these variables.

\section{Electronic Games and Video Games}

The vast majority of teens reported having played video games in the last 12 months (93.3\%). Most play on the computer $(71.9 \%)$, television, PlayStation, WII (71.9\%), and mobile phones $(68.4 \%)$. More girls than boys $(10.5 \%$ vs. $5.5 \%$, respectively) play on tablets ( $p=.05$ ). Playing games on portable devices, such as PSP and DS, were cited by $28.1 \%$ of adolescents and at an arcade by $26.8 \%$.

Most participants usually play both with friends (77.2\%) and alone (73.7\%), 35.1\% play with siblings and $28.1 \%$ with parents. Fourteen percent played with boyfriends or girlfriends and $5.3 \%$ with instructors or teachers. In addition, $10.5 \%$, mainly boys, reported playing with strangers.

Almost half the sample usually plays online (49.1\%). Figure 3 shows the types of electronic games they play. Action/adventure (70.2\%), sports (FIFA, PES, Olympics; 64.9\%), and mobile phone games $(63 \%)$ are most popular. Some significant gender differences were observed. Sports games [X2 $(1, N=57)=11,253$; $p=.001]$ and games of war and strategy [X2 (1, $N=57)=14.760 ; p=.001]$ are more popular among boys, and there was a non-significant tendency of boys to play multiplayer online games (such as Call of Duty, FPS First Person Shooter) and Role-Playing Games (RPG, such as Ragnarok, World of Warcraft, MMOPRG, Hero of Newrth). More girls reported playing games of humor (such as Explosion Man) [X2 $(1, N=57)$ $=4,417 ; p=.036]$ :

In contrast to Internet use, gaming frequency varied widely in the sample. As seen in Table 2, the sample was divided into proposed 


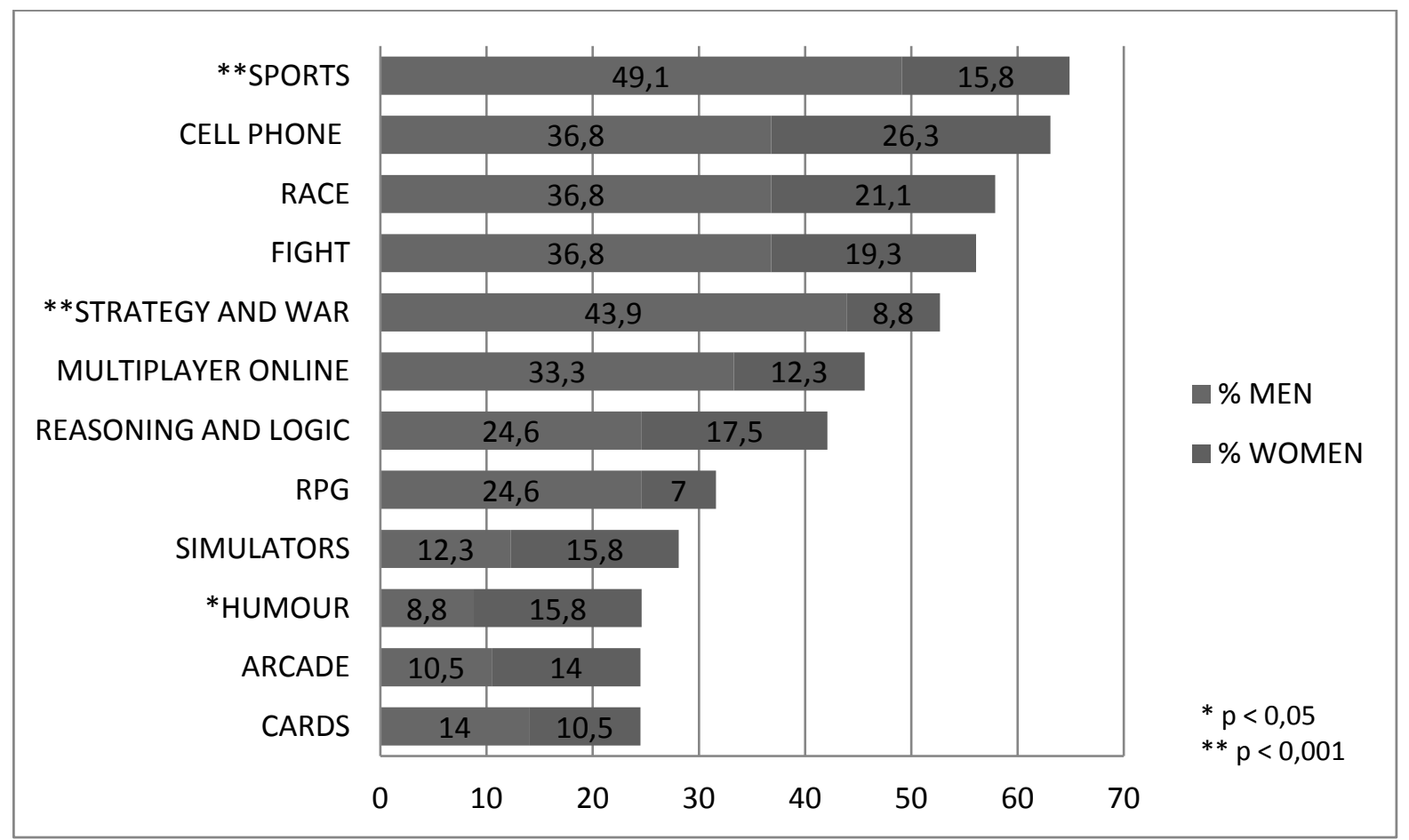

Figure 3. Frequency and percentage of electronic games played by a sample of teenagers that attend Projeto Quixote $(N=57)$.

categories, revealing different degrees of interest in this activity. Concerning when they usually play, a quarter plays from Monday to Friday (24.6\%), and a quarter daily (26.3\%), and half on weekends (49.1\%). The time of the day they play also varied: $26.3 \%$ usually play in the morning, $57.9 \%$ in the afternoon, $54.4 \%$ at night and $24.6 \%$ until after midnight. The average time they play each time varied widely, with more than half of participants $(65.5 \%)$ reporting playing up to two hours per episode. There were no gender differences on any of these variables. As for the locations at they usually play, most reported playing at home $(70 \%)$. However, gender differences were noted here: more girls played at school $(p=.003)$ and more boys played at home $[\mathrm{X} 2(1, N=57)=5,970 ; p=.015]$.

The longest time teens played without interruption varied widely $(M=7,55 \mathrm{~h}, S D=10.5$ ranging from 1 to 72 hours) in the sample. The median was five hours. Boys spent more hours playing than girls $[t(40)=1.97 ; p=.05)$. When asked about what attracts them to the games, most reported that it is the possibility to relax (78.9\%) and the challenge to overcome steps
(70.2\%), followed by playing with friends (64.9\%), observing the game art (54.4\%), being able to play with other virtual players (49.1\%), to vent their anger in the game $(42.1 \%)$, to enter into a fantasy world (35.1\%), and the pleasure of controlling a simulated world (29.8\%). More boys than girls reported being attracted by being able to play with other virtual players [X2 $(1, N$ $=57)=5,388 ; p=.02]$ and to observe the game art $[\mathrm{X} 2(1, N=57)=5.973 ; p=.015]$.

When asked about how they generally feel after playing games with a certain level of violence, $28.1 \%$ reported feeling indifferent; $26.3 \%$ said it depends, if they lose they get angry but if they win they are happy; $12.3 \%$ feel more relaxed; and $10.5 \%$ more aggressive. This kind of game is not played by $22.8 \%$ of participants.

Once starting to play video games, $57.8 \%$ of respondents reported that this kind of game did not interfere with their relationships, but $15.8 \%$ reported spending less time with their "real" friends. On the other hand, $21.1 \%$ reported spending more time with their "real" friends after starting to play. It was noticed that $15.8 \%$ began to interact more with virtual friends. 
Almost half (42.1\%) the adolescents interviewed believe that they are addicted to a game or know someone who cannot stop playing; $29.8 \%$ agree that video games can cause them to be violent; $66.7 \%$ think it is more fun to play with someone than alone; and the same percentage think that video games allow you to do things you cannot do in real life.

Concerning the frequency of other leisure activities, it was observed that the most popular are listening to music (92\%) and watching television $(85 \%)$, practiced daily. The majority of the sample practice sport at least once a week (73\%). However, $13.3 \%$ do not practice at all. A quarter of respondents reported going to pubs once a week and $16 \%$ going every 15 days. Fortyone percent reported hanging out with friends daily. Twenty-nine percent reported reading daily; the same proportion reported that they never have time to "rest and do nothing". Almost half the sample (41.7\%) reported abstaining from doing something to stay connected to the Internet.

\section{Comparison among Adolescents who Reported Being Online for More than Four Hours on Average Daily and those who Spend Less Time Online}

Participants who reported being online for more than four hours at a time, daily, were compared with those who spend less time, on all the variables studied. Significant differences were observed. Adolescents from former group reported using the Internet to work or complete homework $(p=.049)$, maintain a blog [X2 $(1, N$ $=57)=4,479 ; p=.034]$, and talk with boyfriend or girlfriend $(p=.033)$. Fewer teens from this group go offline by themselves [X2 $(1, N=57)$ $=4,776 ; p=.029]$, compared to those who spend less than four hours connected.

More participants from the former group reported playing portable video games [X2 (1, $N=57)=5,608 ; p=.018] ; \mathrm{RPG}[\mathrm{X} 2(1, N=$ $57)=4.913 ; p=.027]$ and simulator games $[\mathrm{X} 2$ $(1, N=57)=4.24 ; p=.035]$. Fewer teens in this group reported playing with instructors of schools or of the projects they attend ( $p=.039$ ).
These teenagers play after midnight $(p=.02)$, and less in LAN houses $(p=.04)$, compared to those in the latter group.

\section{Discussion}

The majority of adolescents interviewed were enrolled in school, use the Internet, play video games, and do not report difficulties online. However, three teenagers reported not using the Internet owing to financial reasons or because they thought they should not. Difficulties reported by some participants that used the web were related to not writing properly or not knowing how to use a computer. It is important to note that the sample was one of adolescents attending a project for socially vulnerable children from families with little education. In addition, although the majority stated attending school, many adolescents are at lower grade at school than they should be, considering their age. Consistent with their socially vulnerable condition, it was observed that they do not spend money to be online; they access the web mainly at home, school, on courses, or via the social project. These results highlight the importance of providing access to the Internet in schools and other locations these teenagers attend as a measure of digital inclusion, as well as of teaching them how to use this resource properly, as pointed out by Livingstone (2014). Furthermore, the results indicate that the Internet might even promote contact among teenagers and their families, as half the participants use it for this purpose; a relevant issue once about a quarter of the teens do not live with their parents. However, the presence of class A and B in the sample drew attention. One explanation for this is that the criterion used was the Brazil Criterion (ABEP, 2012), based on the ownership of utilities. It can be assumed that this data is a representation of what was occurring in Brazil in 2012, when there was a rise in social class owing to higher income and incentive for the purchase of consumer goods. Furthermore, it is important emphasize that the adolescents interviewed attended the activities at the headquarters of the Projeto Quixote and were not the teenagers assisted by educators on the streets. 
The way participants use the web indicates a priority for communication and entertainment: interacting on social network sites, listening to and downloading music. What they like best about the Internet is the possibility for social interaction. These results are consistent with those obtained by the survey conducted in Brazil, Kids Online Brazil 2012 (Barbosa, 2013), and Kids Online Brazil 2013 (Barbosa, 2014), as well as that conducted by comScore (Queiroz, 2015), suggesting that the profile of this sample is consistent with the national reality. The preponderance of social use of the Internet in Brazilian adolescents has already been noted in a study comparing Brazilians and Europeans, which noted that Brazilians use more social networks than do Europeans (Guzzi, 2014).

It is important to emphasize that the proportion of teens that uses the Internet to seek information and for content production, is nevertheless low. Taking into account the need to improve education in the country, Internet use should be encouraged in this regard. Teenagers have access to the Internet, but most learned to use it by themselves or with peers (siblings and friends). Thus, it is important to prepare adults to motivate in young people an interest in online activities that encourage the development of skills such as reading books, producing videos, writing texts, doing research, and taking courses. These activities provide expertise and tools that represent an important means of social inclusion and advantages in the job market. The importance of preparing adults to dominate this technology is already being discussed (Palfrey \& Gasser 2011). Some authors highlight the need for educators to learn to deal with digital resources, since the focus of education for the future is the learning process and not the content itself. They also emphasize that these actions should contribute to an ethical and digital citizenship (Barros, 2013; Pinheiro, 2013; Smith, 2013). Encouraging different activities also contributes to digital maturity. Although Brazilians have been considered digitally mature and most use 11 or more types of online activities (Queiroz, 2015) in this sample, characterized by social vulnerability, only $18 \%$ fell under this category.
Playing electronic games and video games was popular in the teenagers surveyed. Most play for up to two hours per episode, at home, on weekends, and at night. They reference the possibility of relaxing, the challenge of overcoming steps and playing with friends as the aspects that please them most about the activity. The findings reveal that gaming appears to be a ludic activity, consistent with current entertainment, as noted in a previous study with university students (Suzuki et al., 2009). However, the answers draw attention to the relationship between games and violence, a controversial topic in the literature. Some argue that games can incite violence (APA, 2015; Palfret \& Gasser, 2011) or, on the contrary, that games might represent a strategic tool, contributing to the elaboration of conflicts, fears, and anxieties, providing a relief valve (Rossetti, Kuster, Sousa, \& Helm, 2007). Both aspects were observed here. On the one hand, a tenth of adolescents reported becoming more aggressive when they lose electronic games, and one third believes that games can make them more violent. On the other hand, a significant portion use games to vent anger. Aggression has become more present in the replies of this sample than in the previous study (Suzuki et al., 2009). Differences between the realities of the two samples is reflected in these responses. University students are older and have higher educational levels; therefore, they possess greater maturity and can better deal with negative emotions. Teenagers have diminished self control as function of their age (Casey \& Caudle, 2013), which favors emotional responses. Moreover, one may wonder whether the higher level of violent answers in this sample is related to the environment of social vulnerability in which these adolescents live. Thus, aggressive content might not have been caused by the activity of playing itself; rather, the game might facilitate the expression of emotions already present. In this direction, the APA (2015) reports on the influence of violent games on behavior, arguing that there is no single risk factor that could cause a person to act aggressively or violently. It is the accumulation of risk factors that tend to lead to aggressive or violent behavior. The literature review 
here suggests that playing violent video games is one of those factors.

A number of other risks associated with Internet use and of with electronic gaming were identified in the questionnaire responses. The preponderance of connecting the Internet and of video game playing at night contribute to decreased sleep and may have consequences such as daytime sleepiness, decreased school performance and poor health. Furthermore, risks associated with excessive exposure (talking to strangers, pedophilia), aggression (bullying as victim or perpetrator), and viruses were cited. Approximately a quarter reported having had problems with Internet use and almost half believe that the Internet can be addictive. However, they do not always protect themselves. Approximately a quarter of the sample talk to strangers, a third met personally and keep in touch with virtual friends, and more than half have used the webcam. This data is consistent with Kids Online (Barbosa, 2014), which found that 38\% had added unknown people to their contacts. Furthermore, it was noted that $12 \%$ have already accessed pornographic websites. These results reinforce the need for investment in protective measures for safe use of the Internet. Difficulties with user tools, safety devices, privacy settings and policies, reporting mechanisms were found in the European study (Livingstone, 2014) and are evident in the responses of the adolescents interviewed in our study. Guzzi (2014) emphasizes the importance of prevention and of dissemination of sites with this purpose as www. google.com.br/safetycenter and Safernet NGOs. Looking to mitigate security risks, Palfrey and Gasser (2011) suggest the combination of a number of strategies that involve education, technology development, social norms and the law.

Despite of the fact that no scale to measure Internet or gaming addiction have been administered, an analysis was done comparing participants who used the web more than four hours per episode with those who use it for less time and it was found just eventual overuse. Adolescents in the former group use the Internet to do work or homework, maintain their blog and talk more with their boyfriend or girlfriend online, common activities nowadays. However, fewer teens from this group go offline on their own, play video games with school or project's instructors, and, on the other hand, most teenagers of this group play after midnight; play portable video games, RPG and simulator type of game. These results highlight the importance of the presence of adults monitoring Internet use and gaming. There is a tendency to let adolescents surf the Internet or play games at the expense of face-to-face relationships. However, interaction and contact with parents and adults in general are essential to set guidelines and prevent abuse or misuse. What matters is how the person relates to the network or games, realizing the time they spend engaging with these features, being critical about how and for what they use them, knowing how to protect themselves and how to deal with inappropriate content, and feeling secure to report improper approaches. Interaction with adolescents and monitoring their activities make it possible to identify whether there is exaggerated or misuse use of these resources, as the risk of avoiding the challenges of real life for virtual alienation.

Parents and educators often try to prohibit Internet use in order to protect adolescents. However, restricting use does not solve the problem; what is important is to teach safe use and promote digital citizenship (Livingstone, 2014). In this direction, there are initiatives aiming to guide parents, educators, and professionals in this task, such as the psychoeducational website created by the Grupo de Estudos de Adições Tecnológicas (Pican, Moreira, \& Spritzer, 2012).

Finally, analyzing the answers comparing gender differences, it was observed that boys engage more with online friends and play more with these friends; they spend on average more time online; play longer, often until after midnight; and play more sports, strategy, and war games than do girls. The girls reported greater use related to the institution they attend, more frequent use in conversations with boyfriends, and playing more games involving humor than do boys. These differences suggest a profile of greater risk to boys, especially in relation to gaming, as observed in previous studies (Blinka 
\& Smahel, 2011; Suzuki et al., 2009). This variable should be considered when planning activities with this population, mainly to prevent misuse of these technologies.

\section{Final Considerations}

As verified by this study, adolescents in socially vulnerable situations have access to video games and to the Internet and the use is mainly related to leisure and social networking. Young people know the dangers related to these activities, though they do not always take appropriate precautions. The data highlight the importance of training teachers and instructors, and of advising parents, to encourage use that contributes to skill development and to monitoring these activities to avoid misuse or abuse. These recommendations apply to adolescents in general, but are important tools, especially when thinking about promoting opportunities to reduce the prevailing social inequality in the country.

The importance of digital inclusion is indisputable, and digital exclusion is related not only to access to technology, but also to the lack of capacity to take advantage of its potential. Sorj (2003), an author who studies the impact of digital exclusion in social inequality and in the opportunities and quality of life, suggests that digital exclusion has a strong correlation with other forms of social inequality, and, in general, the highest rates of digital exclusion are in lower income areas. According to this author, digital exclusion depends upon five factors that determine the extension of the universality of the technology of information and communication: the existence of physical infrastructure of transmission, equipment and access availability, training in the use of computers and Internet tools, intellectual capacity and social inclusion of the user, and production and use of specific content according to the need of the different segments of the population. It is important to note that the present study highlights the necessity to invest mainly in the last three cited aspects, as teenagers have access to the Internet, but use is limited.
Technology can improve quality of life by enabling access to education, culture, health, communication, services, etc. There is an initiative of the Brazilian government to provide services and information to facilitate the life of citizens, popular participation, and transparency in accountability and management. However, Pinho (2008) notes that this intention is still far from reality. In a study that analyzes government portals of Brazilian states in order to verify how these governments are moving forward in the construction and improvement of democracy using digital media, the author demonstrates that technology alone is not enough; a change in culture that fosters dialogue with society and true social participation is required.

In this direction, successful initiatives to promote training in computing for lower socioeconomic populations should be encouraged. Sorj (2003) describes a project in Rio de Janeiro, Projeto Viva Rio, emphasizing its contribution to education and training, creation of jobs and working sources, combating violence and developing a culture of human rights. This author presents an extensive discussion addressing the relationship between the State, NGOs and social policies, noting challenges that require creative mobilization of new communication technologies against digital exclusion, in favor of the fight against poverty and social inequality. Therefore, the appropriation of technology should be used in favor of citizenship. Investing in training for teens to make good use of information and communication technology can be a decisive contribution in this direction, since today's teenagers will be tomorrow's adults.

A limitation of this study is the small sample size and its restriction to a project developed in the city of São Paulo. In addition, it is important to consider selection bias: teenagers present on the days the interviewers could administer the questionnaire were interviewed at random. A further limitation is the fact that it is based on the self-reports of adolescents. Despite guaranteed confidentiality; adolescents may have omitted or given exaggerated or socially desirable responses. Another limitation is the rapid change in the 
availability and access to the web and to devices such as mobile phones, tablets, and computers. Data were collected in 2012. It is important to conduct further studies with more comprehensive populations.

\section{References}

Abreu, C. N., Eisenstein, E., \& Estefenon, S. G. B. (2013). Vivendo esse mundo digital. Porto Alegre, RS: Artmed.

Abreu, C. N., Karan, G. D., \& Spritzer, D. T. (2008). Dependência de internet e de jogos eletrônicos: Uma revisão. Revista Brasileira de Psiquiatria. 30(2), 156-167.

Almeida, S. P., Bizeto, J., \& Silva, M. T. A. (2007). Análise de comentários espontâneos elaborados por usuários de ecstasy. Revista Panamericana de Salud Pública / Pan American Journal of Public Health 22, 389-395.

American Psychiatry Association. (2013). Internet Gaming Disorder. In Diagnostic and statistical manual of mental disorders (DSM-5). Retrieved from http://www.dsm5.org/Documents/ Internet $\% 20$ Gaming $\% 20$ Disorder $\% 20$ Fact $\% 20$ Sheet.pdf

American Psychological Association, Task Force on Violent Media. (2015). Technical Report on the Review of the Violent Video Game Literature. Retrieved from https://www.apa.org/news/ press/releases/2015/08/technical-violent-games. pdf

Barbosa, A. F. (Coord.). (2013). TIC Kids Online Brasil 2012: Pesquisa sobre o uso da Internet por crianças e adolescentes no Brasil [ICT Kids Online Brazil 2012: Survey on Internet use by children in Brazil]. Retrieved from http://www. cetic.br/media/docs/publicacoes/2/tic-kids-online-2012.pdf

Barbosa, A. F. (Coord.). (2014). TIC Kids Online Brasil 2013: Pesquisa sobre o uso da Internet por crianças e adolescentes no Brasil [ICT Kids Online Brazil 2013: Survey on Internet use by children in Brazil]. Retrieved from http://cetic.br/media/docs/publicacoes/2/tic-kids-online-2013.pdf

Barros, S. P. (2013). A ética, a escola e a formação da cidadania digital. In C. N. Abreu, E. Eisenstein, \& S. G. B. Estefenon, Vivendo esse mundo digital (pp. 175-186). Porto Alegre, RS: Artmed.
Brazilian Association of Research Companies. (2012). Critério de classificação econômica Brasil. Retrieved from http://www.abep.org

Bedoian, G. (Ed.). (2014). O escritório é a escola: Inclusão social no mundo do trabalho. São Paulo, SP: Peirópolis.

Bedoian, G., \& Fender, S. A. (2010). Mundo da familia: Conceitos e manejos do atendimento. São Paulo, SP: Projeto Quixote.

Bedoian, G., \& Lescher, A. (Eds.). (2007). Conceitos e estratégias para o atendimento de crianças e jovens em situação de risco. São Paulo, SP: Projeto Quixote.

Bedoian, G., \& Madalena, R. (2008). Mundo do trabalho e juventude em situação de risco. São Paulo, SP: Projeto Quixote.

Blinka, L., \& Smahel, D. (2011). Dependência virtual de role-playing games. In K. Young \& C. N. Abreu, Dependência de internet: Manual e guia de avaliação e tratamento (pp. 98-117). Porto Alegre, RS: Artmed.

Casey, B. J., \& Caudle, K. (2013). The teenage brain: Self control. Current Directions on Psychological Science, 22(2), 82-87. doi:10.1177/0963721413480170

Guzzi, D. (2014). Dialogo, configurações de privacidade e compartilhamento: Aja, não seja só um observador. In A. F. Barbosa (Coord.), TIC Kids Online Brasil 2013: Pesquisa sobre o uso da Internet por crianças e adolescentes no Brasil [ICT Kids Online Brazil 2013: Survey on Internet use by children in Brazil] (pp. 29-36). Retrieved from http://cetic.br/media/docs/publicacoes/2/tic-kids-online-2013.pdf

Hautefeuille, M., \& Véléa, D. (2010). Les addictions à internet. Paris: Payot \& Rivages.

Instituto Brasileiro de Geografia e Estatística. (2012). Pesquisa nacional por amostra de domicílios. Retrieved from ftp://ftp.ibge.gov.br/ Trabalho_e_Rendimento/Pesquisa_Nacional_ por_Amostra_de_Domicilios_anual/2012/Sintese_Indicadores/comentarios2012.pdf

Livingstone, S. (2014). Recomendações baseadas em evidencias para pais, professores e formuladores de políticas públicas: Uma visão da Europa. In A. F. Barbosa (Coord.), TIC Kids Online Brasil 2013: Pesquisa sobre o uso da Internet por crianças e adolescentes no Brasil [ICT Kids Online Brazil 2013: Survey on Internet use by children in Brazil] (pp. 53-62). Retrieved from 
http://cetic.br/media/docs/publicacoes/2/tickids-online-2013.pdf

Palfrey, J., \& Gasser, U. (2011). Nascidos na era digital: Entendendo a primeira geração de nativos digitais. Porto Alegre, RS: Artmed.

Pican, L. A., Moreira, L. M., \& Spritzer, D. T. (2012). Dependência de tecnologia: Desenvolvimento de um website psicoeducativo. Revista Brasileira de Psicoterapia 14(3), 18-24.

Pinheiro, P. P. (2013). Cidadania e ética digital. In C. N. Abreu, E. Eisenstein, \& S. G. B. Estefenon, Vivendo esse mundo digital (pp. 137-145). Porto Alegre, RS: Artmed.

Pinho, J. A. G. (2008). Investigando portais de governo eletrônico de estados no Brasil: Muita tecnologia, pouca democracia. $R A P, 42(3): 471-93$. Retrieved from http://www.scielo.br/pdf/rap/ v42n3/a03v42n3.pdf

Ponte, C. (2014). Brasil, Portugal e Europa: Gênero e acesso móvel à internet por crianças e adolescentes. In A. F. Barbosa (Coord.), TIC Kids Online Brasil 2013: Pesquisa sobre o uso da Internet por crianças e adolescentes no Brasil [ICT Kids Online Brazil 2012: Survey on Internet use by children in Brazil] (pp. 71-79). Retrieved from http://www.cetic.br/media/docs/publicacoes/2/ tic-kids-online-2012.pdf

Ponte, C., \& Simões, J. A. (2013). Comparando resultados acesso à internet: Brasil, Portugal e Europa. In A. F. Barbosa (Coord.), TIC Kids Online Brasil 2012: Pesquisa sobre o uso da Internet por crianças e adolescentes no Brasil [ICT Kids Online Brazil 2012: Survey on Internet use by children in Brazil] (pp. 27-36). Retrieved from http://www.cetic.br/media/docs/publicacoes/2/ tic-kids-online-2012.pdf
Queiroz, T. (2015, 20 jul.). Maior parte dos brasileiros já pode ser considerada 'madura' digitalmente. Jornal Estado de São Paulo, pp. B8.

Rosseti, C. B., Kuster, P. S., Sousa, M. T. C., \& Leme, M. I. S. (2007). Jogos eletrônicos violentos e estratégias de resolução de conflitos de jovens da cidade de Vitória. Pesquisas e Praticas Psicossociais, 2(1), 173-183.

Silva, P. K. L. (2013). A escola na era digital. In C. N. Abreu, E. Eisenstein, \& S. G. B. Estefenon, Vivendo esse mundo digital (pp. 187-195). Porto Alegre, RS: Artmed.

Sorj, B. (2003). Brasil@povo.com: A luta contra a desigualdade na Sociedade da Informação. Rio de Janeiro, RJ: Zahar. Retrieved from http:// www.bernardosorj.com.br/pdf/Brasil_@_povo_ com.pdf

Suzuki, F. T. I., Matias, M. V., Silva, M. T. A., \& Oliveira M. P. M. T. (2009). O uso de videogames, jogos de computador e internet por uma amostra de universitários da Universidade de São Paulo. Jornal Brasileiro de Psiquiatria, 58(3), 162-168.

Young, K., \& Abreu, C. N. (2011). Dependência de internet: Manual e guia de avaliação e tratamento. Porto Alegre, RS: Artmed.

Recebido: $15 / 12 / 2015$

$1^{a}$ revisão: 16/06/2016

Aceite final: 17/06/2016 